Available online at GSC Online Press Directory

GSC Advanced Research and Reviews e-ISSN: 2582-4597, CODEN (USA): GARRC2

Journal homepage: https://www.gsconlinepress.com/journals/gscarr

(RESEARCH ARTICLE)

\title{
Effect of gastrointestinal nematodes in ram sperm production
}

\author{
Hernández-Russo Zully ${ }^{1,2, *}$, Villegas Nelson ${ }^{1}$ and Fernández-Abella Daniel ${ }^{1}$ \\ ${ }^{1}$ Polo de Producción y Reproducción en Rumiantes. Dpto. Ciencias Biológicas. CENUR L.N. Universidad de la República. \\ Rivera 1350. 50000. Salto. Uruguay. \\ 2 Parasitología y Enfermedades Parasitarias, Facultad de Veterinaria. CENUR L.N. Universidad de la República. Rivera \\ 1350. 50000. Salto. Uruguay.
}

Publication history: Received on 08 April 2020; revised on 16 April 2020; accepted on 17 April 2020

Article DOI: https://doi.org/10.30574/gscarr.2020.3.1.0027

\begin{abstract}
The effect of gastrointestinal nematodes on the sperm production of rams was carried out over a period of 12 months. Two groups of 8 animals were formed each with different treatments. The Control group with the lowest initial parasitic load $(E P G<600)$ who received anthelminthic treatment during the experimental period. Parasitized group with highest initial parasitic load (1000-2800 EPG) and who did not receive anthelminthic treatment during the experimental period. In order to monitor the parasitic load, individual monthly stool test were performed on each animal. Semen was collected by artificial vagina ( 2 ejaculates per day, twice a week). No significant effects were found for body weight and testicular volume, but if significant differences $(\mathrm{p}<0.05)$ were verified for body condition between treatments, in favour of the control group with respect to the Parasitized group. Significant differences $(\mathrm{p}<0.05)$ were found in sperm concentration between the different treatments, $4.8 \%$ above for the Control group. There was no effect of nematodes on ejaculate volume, motility and sperm production. It our conditions (breed, native pasture), the load of gastrointestinal nematodes achieved in the study did not show significant differences in the effect of gastrointestinal parasites on sperm production.
\end{abstract}

Keywords: Ram; Nematodes; Testicle; Sperm production

\section{Introduction}

The nematode infections in grazing sheep affect feed intake [13, 21], lamb growth [4, 16, 24], wool growth associated with a decrease in fibre length and diameter [1,5] sheep and lamb survival and ewe fertility [6, 22, 23]. Also negatively affect the ovulatory rate that is reflected in lower fertility and lead to an increase in foetal loss those results in a detriment of fertility $[6,9$, and 10$]$.

Little is known about how the nematodes regulate sperm production. Gaglio et al. [12] reported some changes in phosphorus, cholesterol and chlorine levels of seminal plasma. On the other hand, Merino sheep selection for number of nematode eggs per gram of faeces (EPG) suggest that rams with low EPG are likely to have higher testis, thereby possibly improving overall flock fertility [19].

The objective of present work was to determine the effect of gastrointestinal nematodes on sperm production of rams under continuous grazing conditions in native pasture.

\footnotetext{
* Corresponding author: Hernández-Russo Zully E-mail address: zhernanrusso@gmail.com
} 


\section{Material and methods}

The experiment was carried out under natural lighting conditions during the autumn in the Experimental Station of the Faculty of Agronomy in Salto, a region in the north of Uruguay (31-23'S; 57-57'W), situated 30 meters above sea level with an average annual rainfall of $1100 \mathrm{~mm}$ and autumn temperatures of about $13-18^{\circ} \mathrm{C}$.

\subsection{Animals}

Sixteen rams Merino Australian and Polwarth (3/4 Merino ancestry), aged of 1 1/2 year old were used. In autumn, the rams were divided into two groups on the basis of parasitic burden, body condition (BC) and live weight (LW) (same BC: 3.8 and LW: $50.8 \mathrm{~kg}$ ).

Group 1 (Control: EPG <600) received drug treatments of Levamisole $(7.5 \mathrm{mg}$ per kg body weight; Ripercol®, Fort Dodge Lab.) three times (March, April and May) in order to minimize the parasitic burden and group 2 (Parasitized: EPG 1000 to 2800) was not dosed.

The treatments began on March 14 and ended on February 21 (next year). The rams were maintained on natural pasture, which had not been grazed by sheep during the previous 12 months.

\subsection{Sampling procedures}

Body condition scored were determined [15] at the beginning and at the end of the treatment period. Each month, the rams were weighed and testicular volume (orchimetry) was estimated, and the faecal samples were collected directly from the rectum to determine number of nematode eggs per gram (EPG). Faecal egg counts were made according to a modified Mc Master method with saturated salts solution [20]. According to other experiments, except in winter, nematode infection is mainly due to Haemonchus contortus (85-87\%) (8-10\% Trichostrongylus spp. and 3-5\% Oesophagostomin spp.) $[5,10]$.

Sperm output as determined by semen collection during the year ( $2 \times 2: 2$ ejaculations/day, twice a week). Semen samples were collected using an artificial vagina $\left(40^{\circ} \mathrm{C}\right)$. Spermatozoa concentration was determined by means of a spectrophotometer (Exylon M722- $325-1000 \mathrm{~nm} / 4 \mathrm{~nm}$ ) according to a standard calibration $\left(\mathrm{r}^{2}=0.95\right)$ ). Sperm motility was measured on a scale of 0-5 [8]. Sperm production was evaluated by determining the volume, motility and concentration of ejaculate [11].

\subsection{Statistical analysis}

Live weight, body condition, testicular volume, sperm traits values, EPG were analysed using the SAS statistical package, GLM (Statistical Analysis System Institute, Windows Version 9.2, 2008). A difference was considered significant at level of $5 \%$. EPG data were transformed logarithmically for statistical analysis.

\section{Results}

\subsection{Body characteristics}

At the beginning of the experiment, body condition and live weight were similar for both groups $(3.8$ and $50.8 \mathrm{Kg}$, respectively). At the end, in group 2 body condition was lower (3.8 vs 3.4; $p<0.05$ ) (Table 1 ). In the Control group body characteristics did not change during experiment period $(p>0.05)$. Live weight was positively correlated with body condition (0.42; $\mathrm{p}=0.04)$.

Testicular volume was similar in both groups during experiment period. There was not significant correlation between live weight and testicular volume (0.08; $>0.05$ ) (Table 2 ). There was a close correlation between testicular volume and ejaculated sperm $(0.68, \mathrm{p}<0.001)$. 
Table 1 Body condition and live weight of rams (Mean + SD).

\begin{tabular}{lcc}
\hline & $\begin{array}{c}\text { GROUP 1 } \\
\text { CONTROL }\end{array}$ & $\begin{array}{l}\text { GROUP 2 } \\
\text { PARASITIZED }\end{array}$ \\
\hline Body condition (0-5) at beginning & $3.80(0.29) \mathrm{a}$ & $3.80(0.35) \mathrm{a}$ \\
Body condition (0-5) at end & $3.90(0.18) \mathrm{a}$ & $3.38(0.24) \mathrm{b}$ \\
Weight at beginning (Kg) & $50.8(2.9) \mathrm{a}$ & $50.8(3.2) \mathrm{a}$ \\
Weight at end (Kg) & $51.8(3.2) \mathrm{a}$ & $49.5(4.4) \mathrm{a}$ \\
\hline
\end{tabular}

Table 2 Live weight and testicular size of rams (Mean + SD).

\begin{tabular}{|c|c|c|c|c|}
\hline & \multicolumn{2}{|c|}{ GROUP 1- CONTROL } & \multicolumn{2}{|c|}{ GROUP 2- PARASITIZED } \\
\hline & Weight (Kg) & $\begin{array}{l}\text { Testis volume } \\
\text { (cc) }\end{array}$ & Weight (Kg) & $\begin{array}{l}\text { Testis volume } \\
\text { (cc) }\end{array}$ \\
\hline March & $50.8(4.0) \mathrm{a}$ & $153(24) a$ & $50.8(4.1) \mathrm{a}$ & 153 (25)a \\
\hline April & 52.4 (5.7)a & 166 (33)a & $51.4(4.9) \mathrm{a}$ & $156(34) a$ \\
\hline May & $45.6(5.0) \mathrm{a}$ & $186(34) a$ & 45.1(4.4)a & 189 (33)a \\
\hline June & $44.6(4.8) \mathrm{a}$ & 149 (30)a & $43.6(5.0) \mathrm{a}$ & $169(35) a$ \\
\hline July & $45.5(5.1) \mathrm{a}$ & $161(34) a$ & $44.0(4.9) \mathrm{a}$ & 175 (39)a \\
\hline August & 44.1 (5.2)a & 204 (38)a & $42.7(5.4) \mathrm{a}$ & 195 (37)a \\
\hline September & 46.1(4.8)a & $192(36) a$ & $47.5(5.0) \mathrm{a}$ & 217 (39)a \\
\hline October & $49.6(5.3) \mathrm{a}$ & 215 (39)a & $48.5(5.1) \mathrm{a}$ & $210(40) a$ \\
\hline November & $50.4(5.4) \mathrm{a}$ & $245(45) a$ & $49.0(5.5) \mathrm{a}$ & $220(38) a$ \\
\hline December & 50.7 (5.7)a & $270(48) a$ & $50.2(5.8) \mathrm{a}$ & 224 (39)a \\
\hline January & $51.7(5.2) \mathrm{a}$ & 280 (53)a & $49.0(5.0) \mathrm{a}$ & $292(50) a$ \\
\hline February & $51.8(5.5) a$ & 260 (51)a & $49.5(5.3) \mathrm{a}$ & $264(52) a$ \\
\hline
\end{tabular}

\subsection{Faecal nematode egg counts (EPG)}

The Control group remained with low EPG counts after administering anthelminthic treatments and throughout the experimental period, increasing in November, December and January to 300 EPG and 550 EPG respectively.

In group 2, the evolution in EPG counts was different, due to the development of the natural biological cycle of parasitic populations found in animals, without intervention of anthelminthic treatments. Low average values (500 EPG) were found in the winter and early and middle spring months, intermediate values (1000-3000 EPG) in the autumn months, and higher values (2000-6000 EPG) in the late spring and summer months (Figure 1).

Estimate of the parasitic load of gastrointestinal nematodes showed differences in EPG between the groups ( $<<0.05)$, with the maximum value of 5728 EPG at the end of the study in group 2 (Parasitized). 


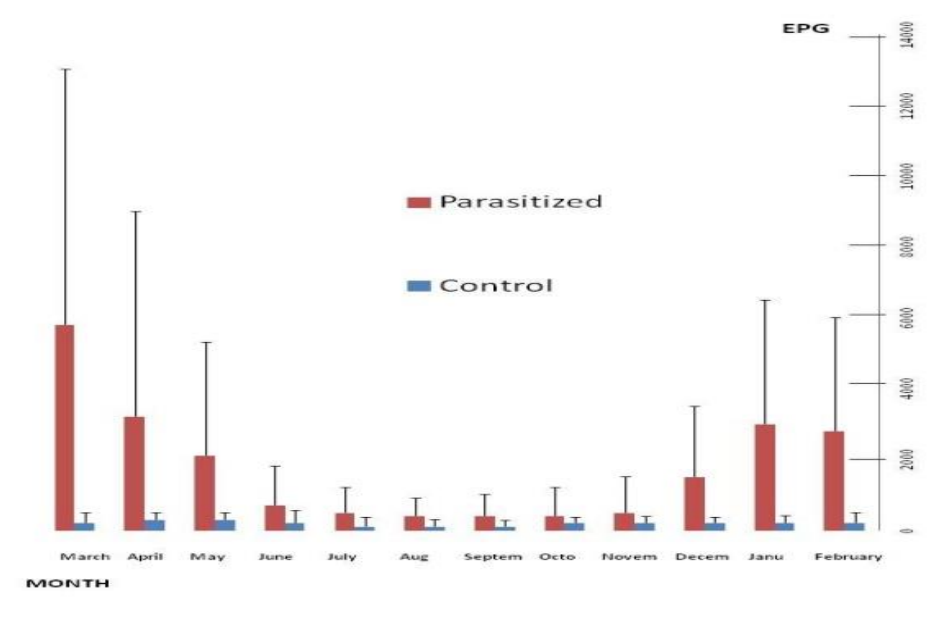

Figure 1 Annual evolution of EPG (mean and standard deviation).

\subsection{Ejaculate characteristic}

Mean annual sperm concentration in the parasitized group rams was significantly lower relative to the control group (3871 vs 4062 sperm $10^{6} / \mathrm{mL}$; $<0.05$ ). For the purpose of assessing the intra-annual evolution of sperm concentration, the data were analyzed averaging the 8 rams ejaculates collected in the month. This allows us to have monthly values and thus be able to identify possible seasonal effects. No significant differences were found in the average monthly sperm concentration ( 30 days) between the Parasitized and Control group; however the trend in all months of the year except April and June was that the parasitized group present values average lower for this parameter relative to the Control group (Table 3).

On the other hand, ejaculate volume and sperm production showed no significant differences ( $\mathrm{p}>0.05$; Table 3$)$.

No differences in motility were found (3.70 vs 3.63: group 1 and 2; mean annual respectively). Winter motility was lower than in the rest of the year $(3.27$ vs $3.90, \mathrm{p}<0.05)$.

Table 3 Ejaculate characteristic (Mean \pm SD).

\begin{tabular}{|c|c|c|c|c|c|c|}
\hline & \multicolumn{3}{|c|}{ GROUP 1- CONTROL } & \multicolumn{3}{|c|}{ GROUP 2- PARASITIZED } \\
\hline & $\begin{array}{l}\text { Concentration } \\
(10.6 / \mathrm{mL})\end{array}$ & Volume (mL) & $\begin{array}{l}\text { Sperm output } \\
(10.6)\end{array}$ & $\begin{array}{l}\text { Concentration } \\
(10.6 / \mathrm{mL})\end{array}$ & Volume (mL) & $\begin{array}{l}\text { Sperm output } \\
(10.6)\end{array}$ \\
\hline March & 3109 (305)a & $0.89(0.17) \mathrm{a}$ & 2770 (415)a & 3066 (4.0)a & $0.97(0.14) a$ & 2940 (490)a \\
\hline April & 3531 (5.7)a & 0.95 (0.13)a & 3363 (545)a & 3662 (5.7)a & $0.90(0.13) a$ & 3338 (496)a \\
\hline May & $3516(5.0) a$ & $0.91(0.14) a$ & 3262 (485)a & $3326(5.0) a$ & $0.90(0.17) a$ & 2991 (402)a \\
\hline June & 3503 (4.8)a & $0.76(0.13) a$ & 2726 (395)a & 3519 (4.8)a & $0.81(0.10) a$ & 2975 (435)a \\
\hline July & 3733 (5.1)a & $0.58(0.14) a$ & $2181(340) a$ & 3473 (5.1)a & $0.56(0.14) a$ & $1979(415) a$ \\
\hline August & 3818 (5.2)a & $0.64(0.18) a$ & 2448 (375)a & $3696(5.2) a$ & $0.56(0.18) a$ & $2074(425) a$ \\
\hline September & 4240 (4.8)a & $0.59(0.16) \mathrm{a}$ & 2447 (349)a & $3828(4.8) \mathrm{a}$ & $0.80(0.13) a$ & 2991 (411)a \\
\hline October & $4750(5.3) a$ & $0.57(0.19) \mathrm{a}$ & 2753 (400)a & 4551 (5.3)a & $0.63(0.13) a$ & 2770 (388)a \\
\hline November & $5072(5.4) a$ & $0.62(0.15) a$ & 3202 (425)a & $4911(5.4) a$ & $0.65(0.15) a$ & 3214 (510)a \\
\hline December & 4667 (5.7)a & $0.74(0.18) a$ & 3494 (445)a & 4351 (5.7)a & $0.75(0.17) a$ & 3290 (411)a \\
\hline January & 4734 (5.2)a & $0.81(0.13) a$ & 4098 (482)a & 4269 (5.2)a & $0.87(0.13) a$ & 3533 (423)a \\
\hline February & $4344(5.5) a$ & $0.88(0.11) \mathrm{a}$ & 3822 (396)a & 4001 (5.5)a & $0.98(0.12) a$ & 3921 (448)a \\
\hline
\end{tabular}




\section{Discussion}

The present study confirms previous reports [7] which indicated that a moderate positive correlation between body condition and live weight ( $\mathrm{r}=0.42$ in this experiment). Literature reported that sperm production is highly related to testicular volume $(0.75-0.80)[17,18]$. Similar results were observed $(r=0.68)$. In addition, the present experiment confirmed results reported by Fernández-Abella y Villegas [7] that in the ram there is no relationship between testicular size and live weight ( $\mathrm{r}=0.08$ ). At the end of experiment (February) the differences recorded in body condition between groups, may be due to the physiological effects caused by nematodes in the organisms as, alteration of appetite as described by Nari and Cardozo [21], Gatongi et al. [13], alteration of tissue synthesis described by Giudici et al.[14], with a reduction in the deposition of fat and protein. Body condition could affect libido, without changing sperm production [8].

The results indicate that anthelminthic treatments (Control group) were effective in controlling parasitic populations present in animals, during all seasons of the year, at least reflected in EPG records. Despite the predisposing beneficial conditions of the climate and the availability of potentially infecting larvae that must have existed from the contamination provided to pasture by the faeces of group Parasitized as a result of the joint grazing of the groups. Lower counts may be due to the ability of animals (hosts) to dispose of adult parasites and/or to inhibit the development of larva 4 stage in the phenomenon of hypobiosis [14].

In Group 2 parasite burden considered as a heavy infection $[14,21]$ showed an effect of the nematodes only on sperm concentration of the ejaculate. In Sarda rams, Gaglio et al. [12] also observed a little difference in sperm concentration between groups (Control and Challenged: oral infection with Haemonchus contortus, Trichostrongylus colubriformis and Teladorsagia circumcincta).

An increase in the sperm concentration of both groups was observed by the effect of photoperiod, as it is known that the testicular weight of the ram, evolves in reverse to the duration of the light hours and it is directly related to the sperm production. However, after November increase sperm concentration of ejaculates is not verified. This could be related to the positive effect of better food $[2,3,8,9]$ in this period according to the quantity and quality of pasture offered especially in spring, which masks the depressive effects of the photoperiod of that time of year on sperm production [8].

Maximum ejaculate volume values were observed in the autumn, confirming what was previously reported on the same flock by Fernández Abella et al. [8].

\section{Conclusion}

In conclusion, in our conditions (breeds and native pasture) nematodes infection reduced ewe fertility [9, 10], conversely according to the present experiment ram fertility no significant change.

\section{Compliance with ethical standards}

\section{Disclosure of conflict of interest}

The authors declared no potential conflicting of interest with respect to the research, authorship and/or publication of this article.

\section{Statement of ethical approval}

This work was approved by the Commission for Animal Experimentation of University of the Republic of Uruguay (CEUA).

\section{References}

[1] Barger IA and Southcott WH. (1975). Trichostrongylosis and wool growth. 3. The wool growth response of resistant grazing sheep to larval challenge. Austr. J. Exp. Agri. Anim. Husb, 15, 167-172.

[2] Braden AWH, Turnbull KE and Mattner PE. (1974). Effect of protein and energy content on the diet on the rate of sperm production in rams. Austr. J. Biol. Sci., 27, 67-74. 
[3] Cameron AWN and Tilbrook AJ. (1990).The rate of production of spermatozoa by rams and its consequences for flock fertility. In Reproductive physiology of Merino Sheep; concepts and consequences. Oldham, C.M.; Martin, G.B. and Purvis, I.W., Eds. Perth. University of Western Australia, 131-141.

[4] Castells D, Nari A, Rizzo E and Marmol E. (1997). Efecto de los nematodes gastrointestinales en la etapa de recría ovina sobre el desempeño productivo posterior. Producción Ovina 10, 9-18.

[5] Hernández-Russo Z, Fernández-Abella D, Kemayd J, Soares de Lima A, Urrutía JI, Villegas N and Bentancur O. (2000). Efecto de los nematodes gastrointestinales sobre la productividad de ovejas Corriedale y Merino. I. Peso vivo y crecimiento de lana. Producción Ovina, 12, 51-62.

[6] Familton AS, Mcanulty RW, Thompson KF and Sedcole JR. (1995). The effect of antithelmintic treatment of ewes during pregnancy. Proc. N.Z. Soc. Anim. Prod, 55, 211-213.

[7] Fernández-Abella D and Villegas N. (1992). Evaluación de diferentes técnicas de medición de la talla testicular y la producción de semen de carnero. Boletín Técnico de Ciencias Biológicas 2, 71-74.

[8] Fernández-Abella D, Villegas N. Echeverría D and Robaina J. (1993). Evaluación de las variaciones estacionales en la producción espermática de cuatro razas. Boletín Técnico de Ciencias Biológicas, 3, 23-34.

[9] Fernández-Abella D, Hernández-Russo Z, Kemayd J, Soares de Lima A, Urrutía JI, Villegas N and Bentancur O. (2000). Efecto de los nematodes gastrointestinales sobre la productividad de ovejas Corriedale y Merino. II. Actividad ovárica, mortalidad y crecimiento de los corderos. Producción Ovina, 12, 105-116.

[10] Fernández-Abella D, Hernández-Russo Z and Villegas N. (2006). Effect of gastrointestinal nematodes on ovulation rate of merino Booroola heterozygote ewes (FecB Fec+). Anim. Res., 55, 545-550.

[11] Fernández-Abella D. (2015). Biotecnogías reproductivas bovinas y ovinas. Editorial Hemisferio SUR- UDELARFacultad de Agronomía, 127-151.

[12] Gaglio G, Poglayen G, Capelli G, Gruner L, Mara L, Giannetto S and Scala A. (2010). Influenece of gastrointestinal trichostrongylidosis on ram fertility. Polish J.Vet.Sci., 13, 743-748.

[13] Gatongi PM, Scott ME, Ranjan, S, Gathuma, JM, Munyua WK, Cheruiyoy H and Prichard RK. (1997). Effects of three nematode anthelmintic treatment regimes on flock performance of sheep and goats under extensive management in semi-arid Kenya. Vet.Parasitol, 68, 323-336.

[14] Giudici C, Entorcasso C and Steffan P. (2013). Biología, fisiología e inmunidad de nematodos gastrointestinales y pulmonares. In Enfermedades parasitarias de importancia clínica y productiva en rumiantes. Ed. Hemisferio Sur. Montevideo, 1-28.

[15] Jeffries BC. (1961). Body condition scoring and its use in management. Tas. J. Agr 32, 19-21.

[16] Kyriazakis I, Anderson DH, Oldham JD, Coop RL and Jackson F. (1996). Long-term subclinical infection with Trichostrongylus colubriformis: effects on food intake, diet selection and performance of growing lambs. Vet. Parasitol. 61, 297-313.

[17] Lindsay DR. (1984). Quantitative requirements of females for spermatozoa and output of spermatozoa by rams. In The male in farm animal reproduction. Current topics in Veterinary Medicine and Animal Science. M. Courot Ed., Martinus Nijhoff Publishers, 324-338.

[18] Lino BF. (1972).The output of spermatozoa in rams. II.Relationship to scrotal circumference, testis weight and the number of spermatozoa in different part o the urogenital tract. Austr. J.Biol.Sci., 25, 259-366.

[19] Matebesi-Ranthino PAM, Cloete SWP, van Wyk JB and Olivier JJ. (2014). Relationships of faecal worm egg count with body weight and male fertility in South African Merino. Proceedings 10th World Congress of Genetics Applied to Livestock Production, 55-57.

[20] MAFF. (1986). Manual of Veterinary Parasitological Laboratory Techniques. 3th ed. Her Majesty's Stationery Office, London.

[21] Nari A and Cardozo H. (1987). Enfermedades gastrointestinales in: Bonino J., Durán del Campo A., Mari J.J. (Ed), Enfermedades de los Lanares, Hemisferio Sur, Montevideo, 91-107.

[22] Ramírez-Restrepo CA and Barry TN. (2005). Alternative temperate forages containing secondary compounds for improving sustainable productivity in grazing ruminants. Review. Anim. Feed Sci. Technol, 120, 179-201. 
[23] Thomson EF, Gruner L, Bahhady F, Orita G, Termanini A, Ferdarwi AK and Hreitani H. (2000). Effects of gastrointestinal and lungworm nematode infections on ewe productivity in farm flocks under variable rainfall conditions in Syria. Livest Prod. Sci., 63, 65-75.

[24] Waller PJ and Thomas RJ. (1981). The natural regulation of Trichostrongylus spp. populations in young grazing sheep. Vet. Parasitol, 9, 47-55.

\section{How to cite this article}

Hernández-Russo Z, Villegas N and Fernández-Abella D. (2020). Effect of gastrointestinal nematodes in ram sperm production. GSC Advanced Research and Reviews, 3(1), 19-25. 